\title{
Some Aspects to the Rehabilitation of the Vernacular Adobe Architecture
}

\author{
Á. Nemcsics ${ }^{1}$, A. Ürmös², G. Gröller \\ 10buda University, Research Group of Materials and Environmental Science; nemcsics.akos@uni-obuda.hu \\ 20buda University, Research Group of Materials and Environmental Science; urmos.antal@uni-obuda.hu \\ 30buda University, Research Group of Materials and Environmental Science; groller.gyorgy@uni-obuda.hu
}

Abstract. In this paper, we are dealing with the heat-technical modeling, life cycle assessment and the conservation of the vernacular adobe wall house. One of our investigations is directed to the seasonal equalizing property of this wall structure. The reason of this choice of this topic can be found in the fact, that in the old Hungarian folk house construction, the abode wall was popular and a significant fraction of the people living in the countryside are still inhabit these old houses. The Hungarian winter is cold and followed normally by sizzling hot summer. The adobe wall construction is perfect for the local climatic conditions. Due to the on-going global warming up, the ecological importance of these wall constructions is becoming more prominent. Most of these adobe wall constructed houses are already under preservation order, due to their ecological significance and also because they are part of our culture heritage. Their conservation and maintenance problems are briefly described in the paper, too.

Keywords: adobe wall, heat balance, modelling, life cycle assesment, renovation

\section{Introduction}

The vernacular architecture, can serve as exemplar for the ecological architecture from both viewpoints such as material and structure usage [1]. During the centuries and the millennia, an optimized material selection and structural solution is formed. These solutions can be observed in the folk architecture remained to us. The folk architecture is typically architecture in villages. In Europe, in the 20th century, the building stock is drastically changed. These old buildings are largely demolished because of the increasing comfort requirements and new buildings have built instead of them. By the demolition of the traditional old buildings, our cultural heritage has suffered significant damage. In the economically less opulent areas, this transformation was slowly. So, significant cultural heritage was preserved. By the application of the modern high-tech, these old folk buildings can be renovated and can be made more comfortable.

The vernacular architecture can adapt to the local environment (Fig. 1.). The vernacular architecture uses local building materials, such as wood, stone, earth for the building construction [1]. The selection of the building material is ecological, because they do not need additional energy production. Furthermore, the building materials and the constructions fit to the local climate. In the mountains or in the colder climate area, the construction from wood is specific. In one hand, the wood as raw material is given by the forest, on the other hand, the wall made from wood has a very good thermal isolation. In the area of warm and dry climate, large mass constructions and large 
specific heat-coefficient materials are expedient. So, in such areas, the buildings are from stone or earth. In the rainy areas, the high picked roof is expedient. In the dry areas, the flat roofs serve for the precipitation of the rainfall expedient.

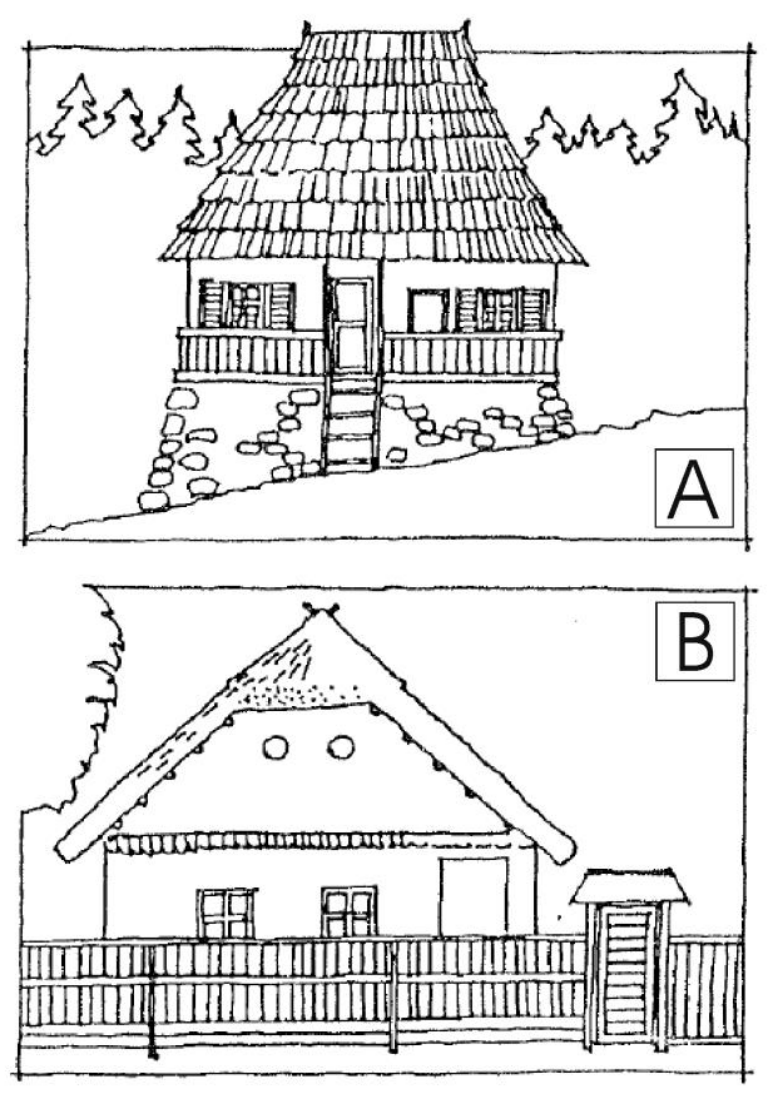

Figure 1. The vernacular architecture fits to the environment (morphology, climate etc.) Hungarian vernacular house in mountainous district (Csík region) (A) and in lowland (Alföld region) (B) [1]

Because of the above mentioned economical reason, in the Carpathian basin, significant vernacular architecture as cultural heritage was remained. Whereas these old vernacular buildings did not replaced with new houses only by economic reasons. Unfortunately, among the inhabitants, the old house symbolizes the poverty, so the honor of these old houses is not appropriate. In Hungary, the specific climate is the warm summer and cold winter, so a large mass and large specific heatcoefficient walling is expedient. So in this area, in the folk architecture, the adobe wall buildings was popular (Fig. 2) [2]. 

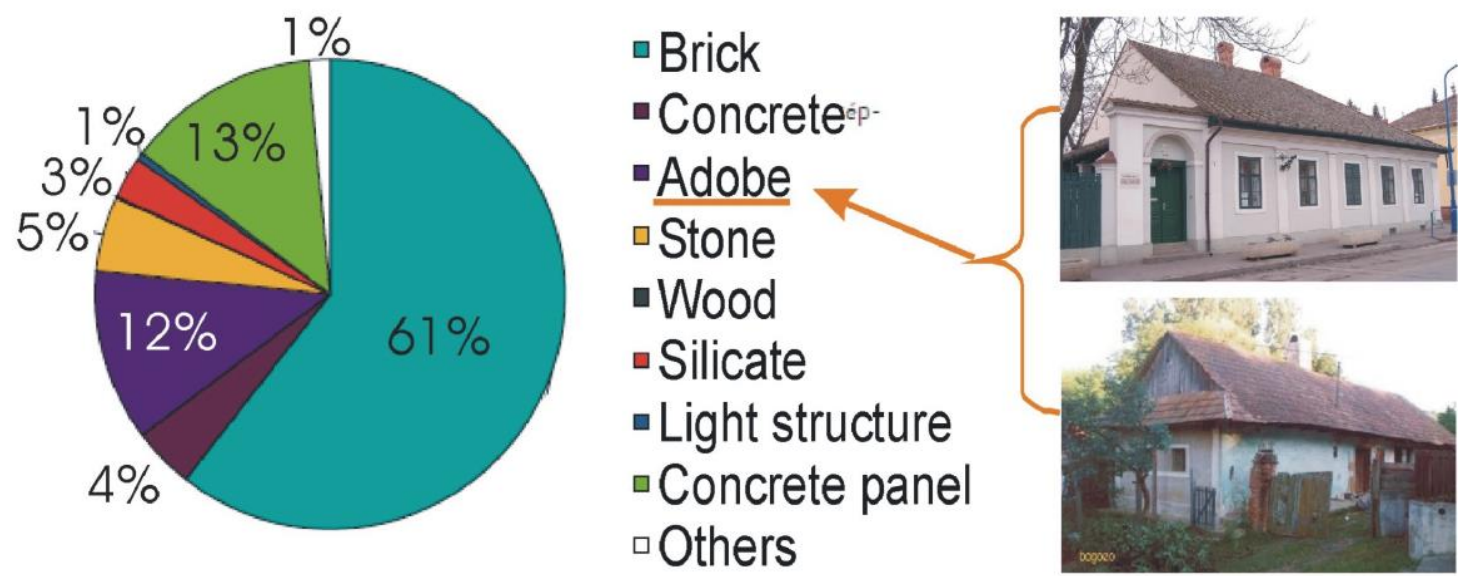

Figure 2. The building stock in Hungary according the building material. Significant amounts (12\%) of the building are still from adobe especially in flatland.[2]

Actually, in Hungary, more than $10 \%$ of the building stock, is adobe wall building. Overwhelming of them represents cultural heritage, i.e. these houses can be declared as monuments (Fig. 3.) [3].
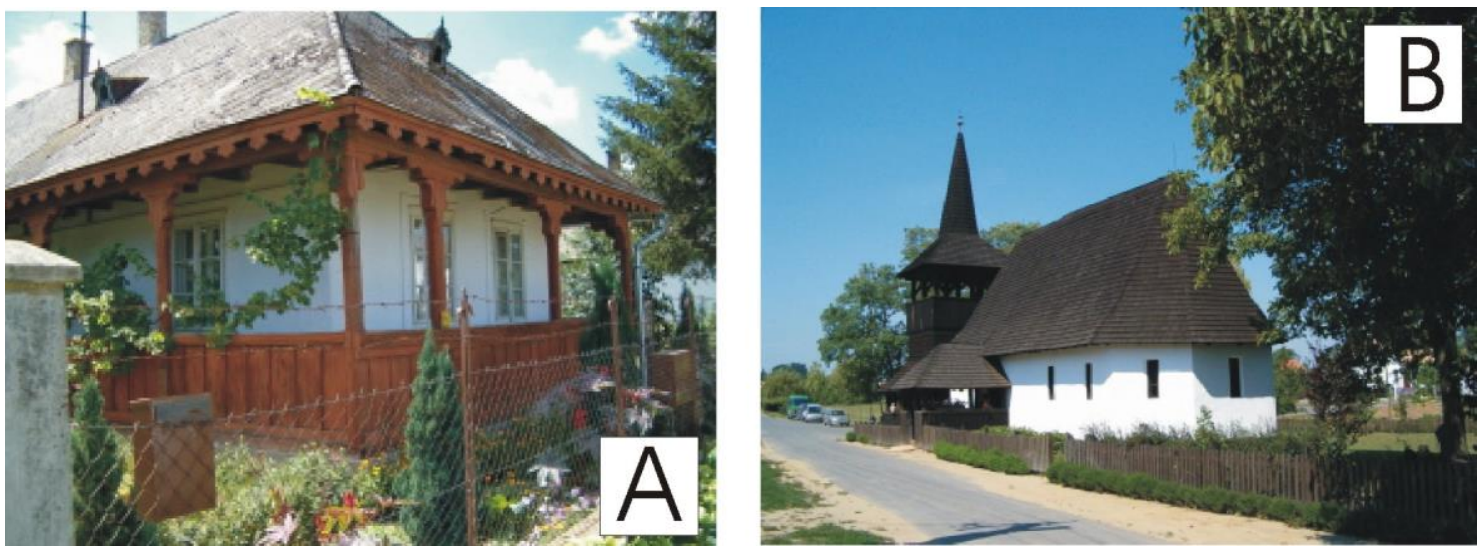

Figure 3. Adobe wall houses from north part of Hungary. (A) a family house, (B) a church (Tákos). (photographed by the first author)

\section{Some aspects to the construction and climate}

In the history, the building from adobe and from earth is very old technology. Thousands of years old adobe wall building and building residuals remained for us. The adobe walling under dry condition is very hard, indefatigable, and also durable. The single enemy of this structure is the water. Because of the effect of much humidity, it loses its stability. So, it is necessary to protect it from the rain and from the ground water. As example, the more thousands years old building conservation, the Limestone Mosaic Church in the town Uruk in Mesopotamia have to mention [3].

The adobe walling consists of a special kind of composite material, where the matrix is the clay and the fibrous material is the chaff. Because of the homogeneous mixing, this walling structure has 
anisotropic mechanical properties. The anisotropic structure has larger resistivity against the random directed forces such as earthquakes compared to isotropic walling structure. In Hungary, the strong earthquakes are rarely $[4,5]$. So, these houses endures these environmental circumstances such as weak earthquakes.

The adobe wall house is healthy. Not only the thermo balancing ability adobe wall is very good, but its humidity balance attribution as well. Because of the cheap, local raw material, and good building physical properties, the adobe-architecture becomes into fashion again. In Europe, mainly residential houses build from it, but in Africa, and in South-Asia, the adobe wall public buildings (church, schools etc.) are also frequent. The technology of the construction from the adobe wall is very diverse [6-19].

The building from brick shaped adobe elements, dried in the sun, is also possible. The sliding frame technology is also a solution. The flickered - plastered structure among the twig frame is a further possibility. In Hungary, in the vernacular architecture, all of these three technologies were common. Nowadays, the first two solutions are rather used again. The stokers constructed from the adobe were also very popular. The flickered clay to the wood frame, during the first heating burned out and the clay changed into the tile material.
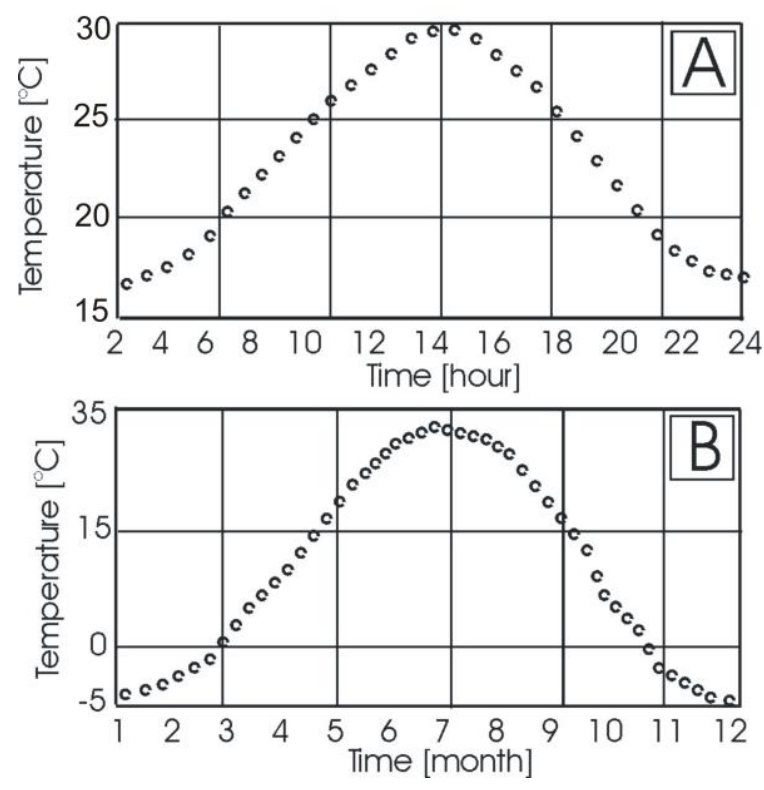

Figure 4. The temperature change versus time for different periods. (A) summer day, (B) year [20]

The adobe wall architecture is excellent for the Hungarian climate. It is necessary to store large amount of heat. Because of the global warming up, the summers are getting hotter. The heat storage capability of newly built hollow brick and lightweight constructed houses are not appropriate [1]. That's why, there are lots of air conditioning equipments in the newly build houses. The well heat insulated lightweight constructed houses are appropriate in the north and mountain areas, where 
the summer air temperature not exceed the 20-25 ${ }^{\circ} \mathrm{C}$. The Hungarian climate in the past 25-30 years changed a lot. It is very frequent, that the summer is warmer than $35^{\circ} \mathrm{C}$. While earlier, warmer than $30{ }^{\circ} \mathrm{C}$ was an extraordinary case and counted very hot.

The local people are not accustomed to the recent warmed up climate, therefore the using air conditioning equipment is frequent. Unfortunately, these instruments neither operated by solar cell, but by network current from power station, which causes positive feedback, as regards $\mathrm{CO}_{2}$ emission and global warming up [2]. In our calculations we consider the average of our many years of solar radiation access and heat measurements. The annual temperature changes (i.e. excitation) can be well approximated by sine function. The temperature waving shows a good correlation with the fluctuation of sun radiation (Fig. 4.) [20,21].

\section{Heat technical investigation}

In the practice, the thermal sizing of the buildings and building structures are usually solved for stationary state $[22,23]$. For the building permit of the houses, the office requests the heat-technical calculation, for stationary state. For this description they use a simple electro-technical model, where the wall or the wall structure is represented by one or more resistances connected in series. The inner and outer temperature difference satisfies to the potential difference, which we switched to a one-resistor circuit. The temperature profile, formed along the cross-section of the wall can be determined by the voltage drop on resistors. A necessary parameter for the calculation is the heat transfer coefficient $(\alpha)$, and the thermal conductivity $(\lambda)$, which parameters can be found in the literature $[22,23]$. The above mentioned stationary model does not correctly describe all of thermal behaviors. For example, we did not consider the heat-storage capability. So, it is necessary to extend with the slowly-changing anstationary case. Let we see a simple homogenous wall structure, like the adobe wall is. As we seen in the previous chapter, in the examined climate, the thermal profile gives a good approximation of sinus function, which is in the terminology of the electro-technical description, means harmonic excitation. In our case, the heat-capacity of air, which is bound the wall is much smaller than the wall structure, so in first approximation, we can neglect the calculation of the heat transfer coefficient $(\alpha)$. So the electrical equivalent circuit of the wall construction consists a resistance $(d / \lambda)$ and an impedance $(A / \mathrm{cm})$, which are parallel connected each other, where $d$ is the wall thickness, $A$ is the normalized area, $c$ is specific heat capacitance, $m$ is the normalized mass of the walling [20]. 


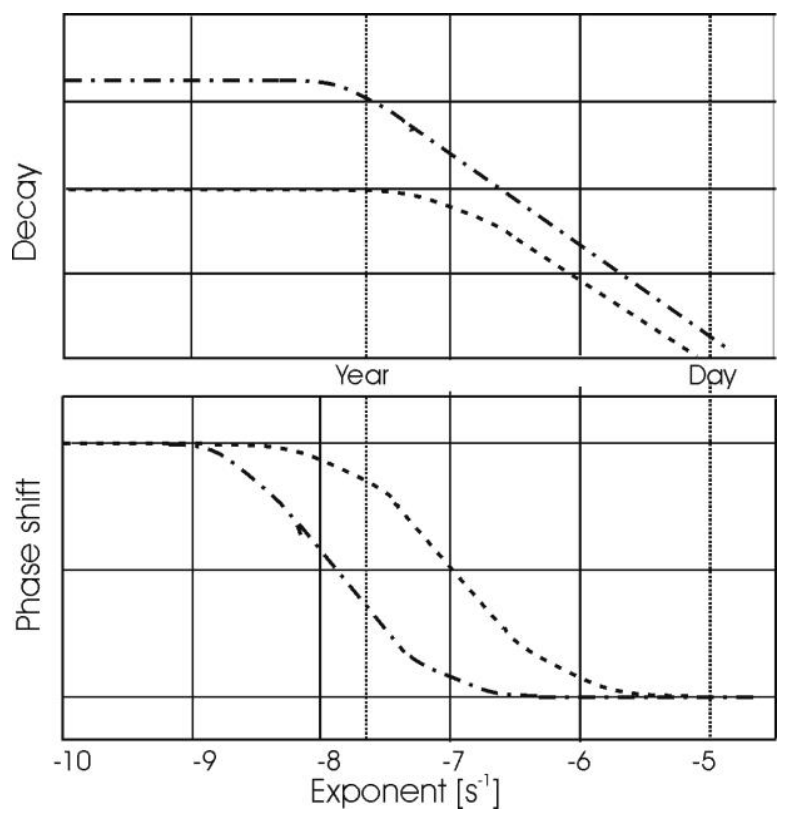

Figure 5. Characteristics of intensity decay and phase shift for different building materials. Dotted-dashed and dashed lines represent the adobe and a brick wall structures, respectively. [20]

The behaviour of an unstationer case can be described also with an electrical network consisted not only from serial resistances but extended with parallel capacitances, too. Let's do an examination with typical data. We take a $50 \mathrm{~cm}$ thick adobe wall, which is common in the vernacular architecture. Where this wall is not complete isolated from ground. Therefore the moisture content of the wall is variable. So we became the building physics parameters the following values: The wall density is $\rho=2000 \mathrm{~kg} / \mathrm{m}^{3}$, the heat-capacitance is $c=1-3 \mathrm{~kJ} / \mathrm{kgK}$, the heat conduction is $\lambda=0.64$ $\mathrm{W} / \mathrm{mK}$. The amplitude (or decay) and phase characteristics are shown in the (Fig. 5.). (The phase and amplitude characteristics can be derived from the s si "reflexion" parameter [24-26].) Here, the characteristics calculated for two different building materials (such as for adobe and for brick) are compared.

Nowadays, in Hungary, the $38 \mathrm{~cm}$ thick brick wall is the most common walling structure. Because of the comparison, investigate our data for this wall type, which details is $\rho=1700 \mathrm{~kg} / \mathrm{m}^{3}, c=0.88$ $\mathrm{kJ} / \mathrm{kgK}, \lambda=0.72 \mathrm{~W} /(\mathrm{mK})$. On the figure, vertical lines indicate the values, corresponding the day and year. It is readable from the figure, that the heat balance of the adobe wall is larger than the brick walling in regard to one year. The thermo-technical operation of the adobe walling shows not only phase shift but also hysteretic behavior. The stored heat and its detailed calculation described elsewhere [20].

\section{Life cycle assessment}

Let's compare the adobe walling buildings and the brick houses from the viewpoint of lifecycle, and their effects on the environment [28-30]. We mentioned above, that the adobe wall building needs only winter heating. In summer, its inner climate is very comfortable. In the fresh constructed 
houses, it is possible, that it needs lower winter heating, because the better thermal insulation, but in summer time, the inner part of the building often overheats.
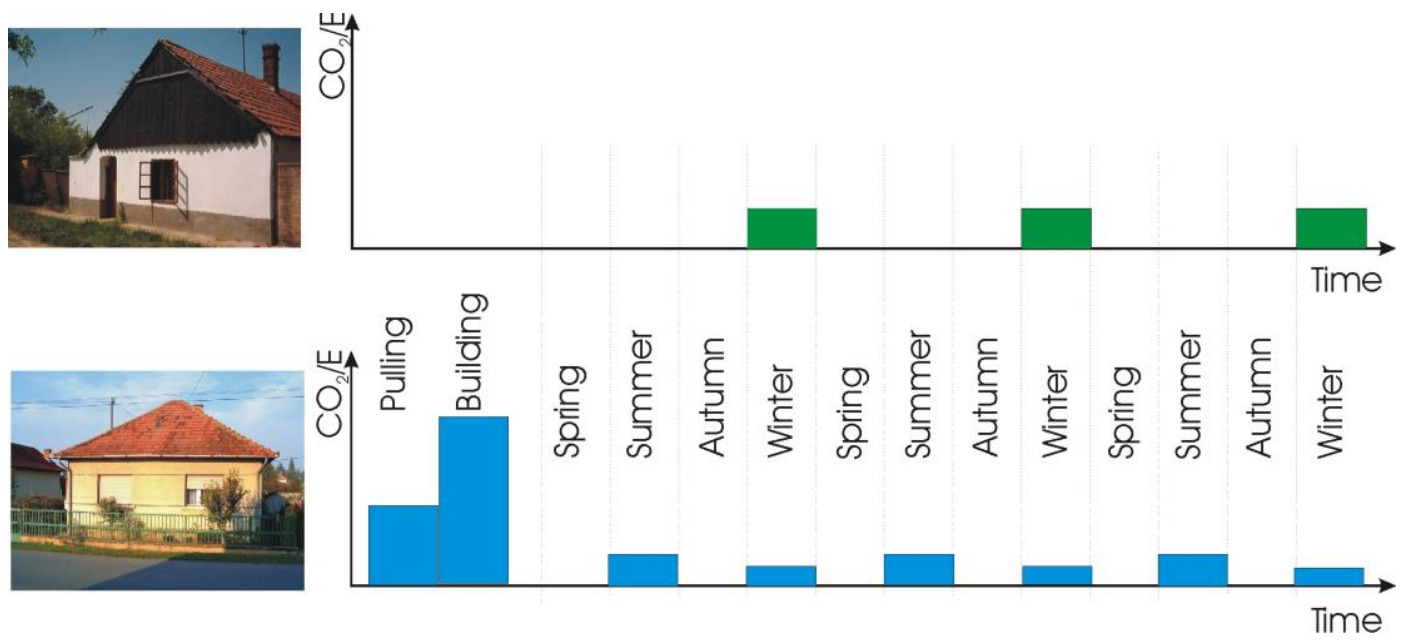

Figure 6. Comparison of the life cycle (energy consumption such as heating, cooling and energy demand of the replacement) for an original adobe wall house (upper part) and a brick wall house (lower part) substituted the original building.

Against the summer warming, many use air conditioning. So the adobe wall house energetically is favorable. The demolition of the adobe wall house and the construction of the new house need also energy (Fig. 6.). The values on the graph are in arbitary units, which serve for for comparative purposes only. Furthermore, the adobe wall houses represent frequently cultural heritage. Hereinafter we show, how can we take it more comfortable [27].
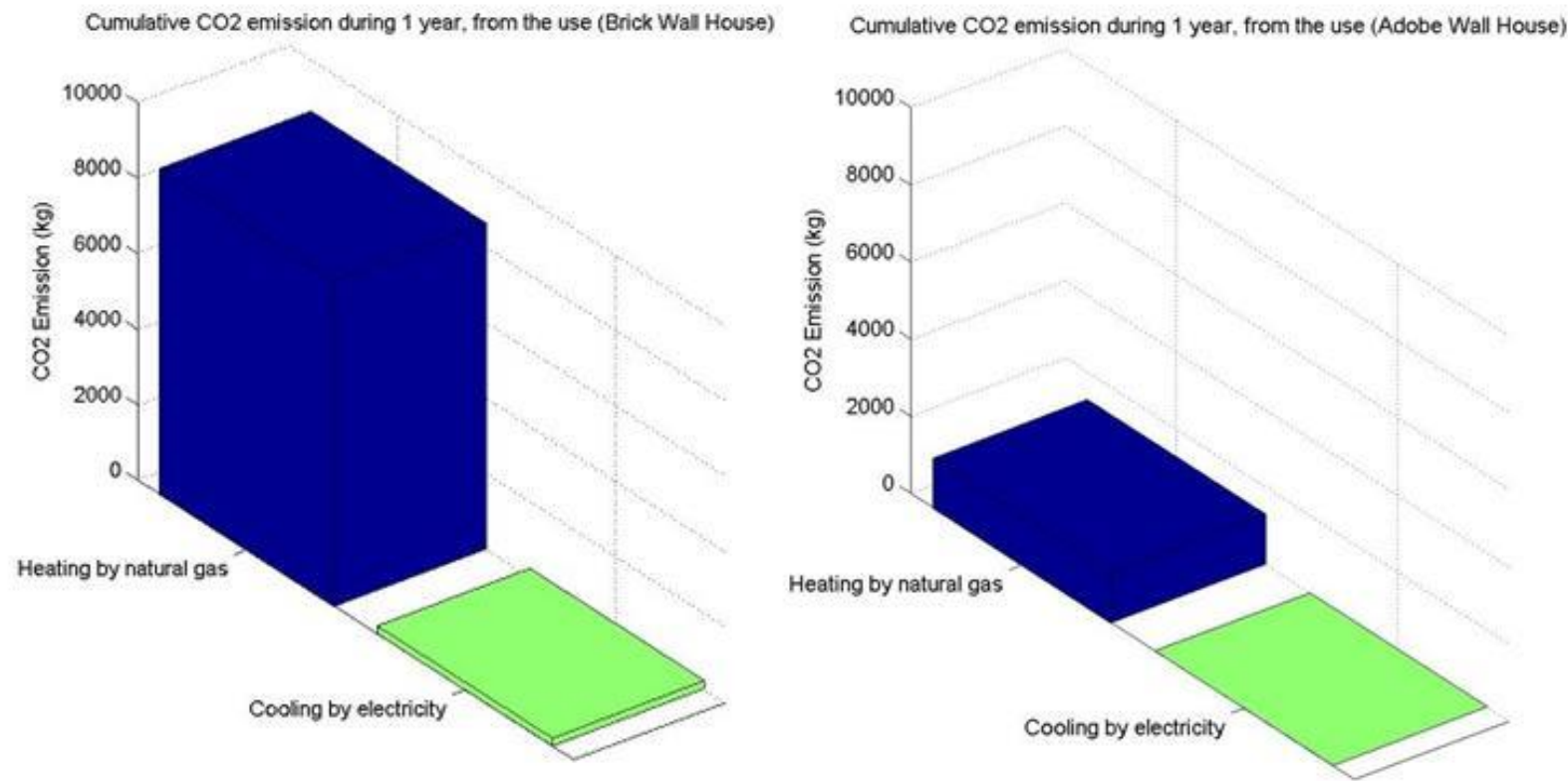

Figure 7. The annual $\mathrm{CO}_{2}$ emission of the brick house and the adobe wall house. (Source: Produced with the help of LCA program GaBi.) 
In the following in the frame of life cycle assessment, the adobe wall house and the brick house in the view point of annual $\mathrm{CO}_{2}$ emission are compared. For the correct comparison of the houses, they have the same $\left(75 \mathrm{~m}^{2}\right.$ ) floor area. (The brick wall house was produced from HB 38-19/14 N+F type brick, where the size is $380 \times 185 \times 140 \mathrm{~mm}$ and its thermal conductivity coefficient is 0.46 $\mathrm{W} /(\mathrm{mK}))$. During the calculations, the amortization of the tools, the building times, the number of the workmen's (and its salary) are neglected. Both building are built by local workmen. The foundation of the brick wall building is built from local raw materials, in case of adobe wall building, this is not necessary. The wall of the investigated buildings are not heat insulated. In the calculation, the pine tree roof structure and the doors and windows are produced by local carpenters from local raw material. In case of both buildings, same tiles (Tondach TWIST XXL) are used. The ceiling of the brick wall house is a $7.5 \mathrm{~cm}$ thick reinforced concrete slab, while the ceiling of the adobe wall house is a dust slab (with $2.5 \mathrm{~cm}$ thick board cover on the beams, with sealed gaps).

The orientations of the buildings are also the same (North-South). The heat demand of the buildings are estimated by the calculation of the inner and outer transmission and the filtration heat current, with the consideration of the allowances (e.g. direction, wind, and the heat sensing allowance). The heat current from sunbeam, the inner heat production and the heat amount for the hot water production are not considered. The transmission heat current is the heat amount, which passes through the wall and the filtration heat is the heat amount, necessary for the heat up of the air, comes from outside environment, through the doors and windows.

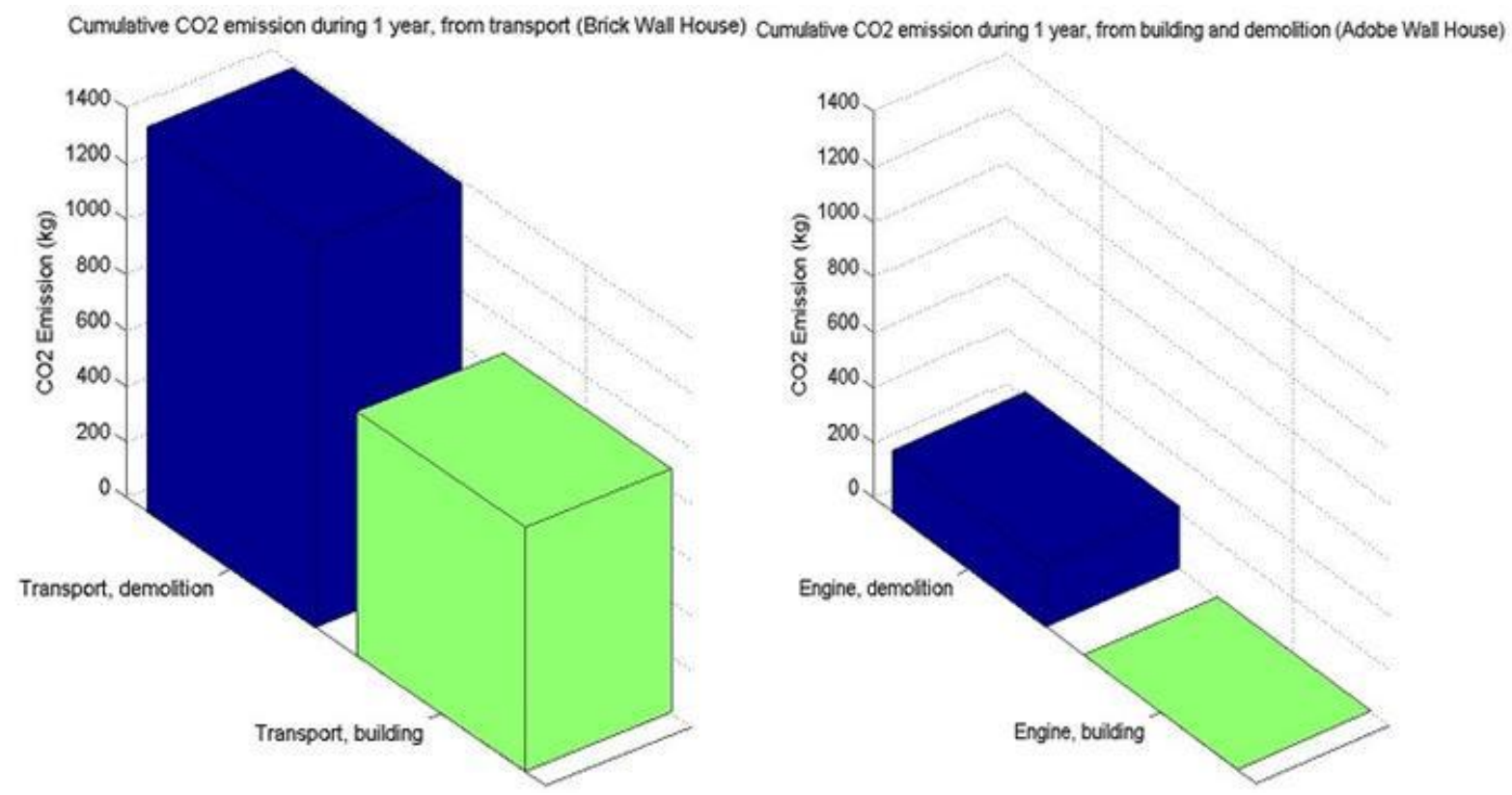

Figure 8. The $\mathrm{CO}_{2}$ emission of the brick house and the adobe wall house during the building and demolition processes. (Source: Produced with the help of LCA program GaBi.)

In the Figure 7 the calculated annual $\mathrm{CO}_{2}$ emission of the brick house and the adobe wall house are shown. The presented values originate from a computer simulation ("Gabi" LCA software PE system), where the flat area are the same [31,32]. The calculation methodology was the following: in 
the first step, the heat loss was calculated between each of the neighbouring rooms and the outer space as well. In this stage a three-room building was considered, with a room, a bathroom and a kitchen. The temperature of the room is $20^{\circ} \mathrm{C}$, the kitchen is $18{ }^{\circ} \mathrm{C}$ and the bathroom is $24{ }^{\circ} \mathrm{C}$. With these temperature data, the total lost heat amount was calculated. Second, the $\mathrm{CO}_{2}$ amount was calculated with software. In this figure, the blue column represents the $\mathrm{CO}_{2}$ emission from the heat, and the green column represents the $\mathrm{CO}_{2}$ emission from the cooling. In both cases the same condensation boiler (VICTRIX $12 \mathrm{~kW}$, with 50/30 thermal degree step) was chosen. The fuel is natural gas. The annual heating $\mathrm{CO}_{2}$ emission of the brick house is $8620.1 \mathrm{~kg}$ and the adobe wall house is $1285.4 \mathrm{~kg}$. In case of the brick wall house is a split air conditioning equipment (Samsung Ar09fssyawtneu) and this is not necessary for the adobe wall house. The annual cooling $\mathrm{CO}_{2}$ emission of the brick house is $215.2 \mathrm{~kg}$. In the diagram, it can be seen that the annual $\mathrm{CO}_{2}$ emission of the adobe wall house are smaller, than the brick house. This is due to the bigger thickness and the larger heat capacitance of the adobe wall, whereupon it cool down and heat up more slower, than the wall of the brick wall building.

In the Fig 8., $\mathrm{CO}_{2}$ emission of the brick house and the adobe wall house are shown during the building (blue columns) and the demolition (green columns). In the case of brick wall house, during the building process the brick is transported (diesel truck, with Euro-3 motor, which cargo capacity is 12 ton, 5 ton payload) to the place of the building. The $\mathrm{CO}_{2}$ emission in this case is $878.18 \mathrm{~kg}$. During the demolition process, the dust is transported by the same kind of truck. The $\mathrm{CO}_{2}$ emission in this case is $1384.57 \mathrm{~kg}$.
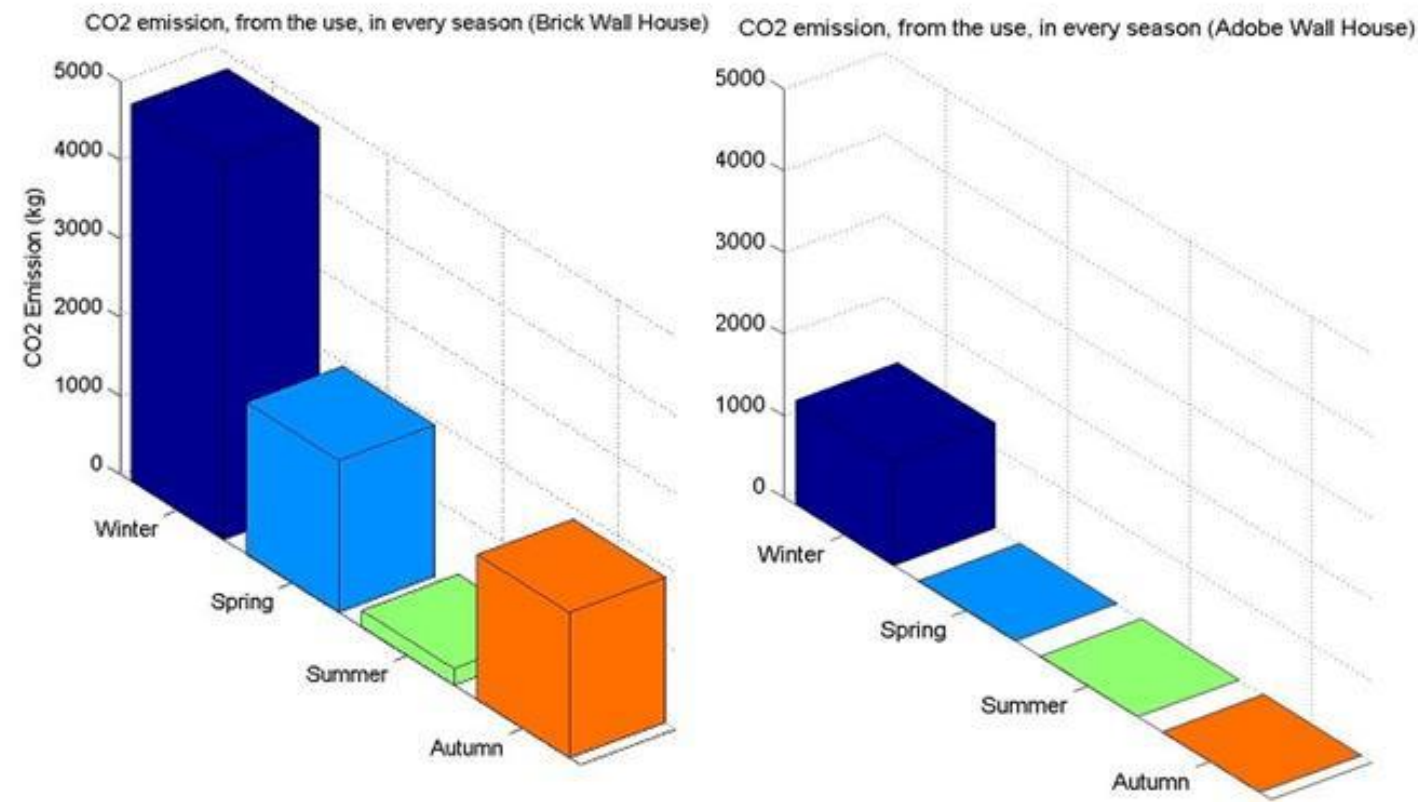

Figure 9. The $\mathrm{CO}_{2}$ emission of the brick house and the adobe wall house during the four seasons. (Source: Produced with the help of LCA program GaBi.)

These two values are different, because in the case of demolition, the dust of the undercoat is also transported elsewhere. In the case of the adobe wall, in the building process the adobe wall is constructed by manual force, by the cradling method, using local raw materials (clay, straw). 
Because of this, there is no $\mathrm{CO}_{2}$ emission during the building process. During the demolition - in order to save time - an engine (CATERPILLAR D6R II LGP) was used (its fuel is diesel oil, 15 litre in each work hour; the total working time is 5 days and 10 hours in each day). The $\mathrm{CO}_{2}$ emission in this case is $223 \mathrm{~kg}$. In both cases, the roof structures are burned. This could not cause extra $\mathrm{CO}_{2}$ emission, because in this case the same amount of $\mathrm{CO}_{2}$ is released, which stored in the wood.

In the Fig. 9., the $\mathrm{CO}_{2}$ emission of the brick house and the adobe wall house are shown in each seasons. If we compare these two data series, it can be seen that the $\mathrm{CO}_{2}$ emission during the seasons, the brick house larger, than the adobe wall building.

The reason of this, that during the heating period (spring, autumn and winter), the brick house always need heating, because the walls are relative thin and their heat capacitance is small, so the building cools rapidly. Because of the same reasons, in summer time, the brick wall building also heat up rapidly. It should be noted, that only the rooms have air conditioning equipment. In contrary, in the case of adobe wall building, air conditioning equipment is not necessary. In winter time only, an auxiliary heating is necessary.

The qualitative $\mathrm{CO}_{2}$ emissions (originate from heating and cooling, without hot water supply) of the adobe house and the brick house are the following: In winter time, they are $1285.4 \mathrm{~kg}$ and 4798.8 $\mathrm{kg}$, respectively. In spring time, they are $130 \mathrm{~kg}$ and $1934.5 \mathrm{~kg}$, respectively. In summer time, they are $0 \mathrm{~kg}$ and $214,2 \mathrm{~kg}$, respectively. In autumm time, they are $110 \mathrm{~kg}$ and 1847,8 kg, respectively.

\section{Rehabilitation of the old adobe building}

In a regrettable manner, in Hungary, among the population of the country, the poverty and the underdevelopment are associated to the adobe walling houses. Therefore, if they can do, they demolish the adobe wall house and build a brick house instead of this. Among the educated population, the construction from adobe clay is spreading again. The university or college educated people are environmentally conscious and they looking for the healthier and more environmentally friendly solutions. Nowadays, already appear publications related to adobe clay architecture, but this is always very few, for the change the point of view. 

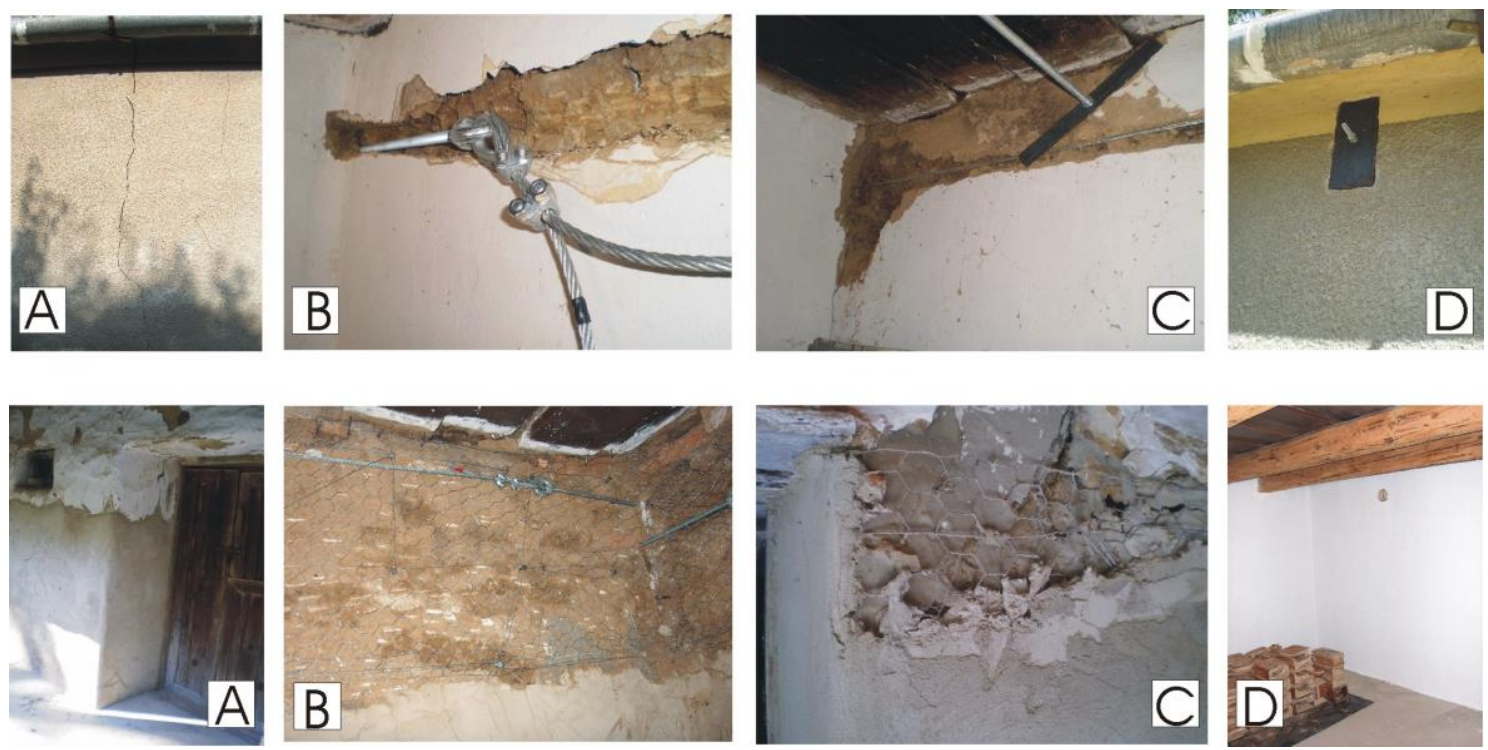

Figure 10. Two renovation processes of the adobe house. Upper part: strengthening of the upper part of the walling: $(A)$ splitting (B) connection of the cable-rope to the screw (C) The streched cable-rope in inside (D) The screw with underlay in outside. Lower part: Strengthening of the surface: (A) the moulding surface in outside (B) the wire mesh mounted on the wall (C) rough-casting (D) polished plastering in inside.( Source: Experimental work by the first author)

The largest objection against the adobe walling buildings, that they are not comfortable. Today this objection cannot cope its place, because the application of the high-tech (e.g. water insulation) any of the wet room is constructable in this. In many cases the dwellers shame themselves, that they live in adobe building, therefore they shape and plaster the appearance of their house, as if would brick wall. It is true, that the excellent building physical feature retains, but the value of cultural heritage is lost.

As mentioned before, the adobe walling must be protected against the water (the rain, splashed water and the ground water). The one of the most important thing, that the roof structure and the coverage of the house must be perfect. We can protect ourselves by surface cover, against the splashed water. There are many kind of water insulation exist, against the ground water (pressed metal plate into the wall, chemical material to the drill hole etc.).

In many cases, we have to renew neglected buildings. Because of the injured roof and continuous rain can be happen, that the wall cracks. Above all, it needs to eliminate the reasons of these cracks. The next step is, that these cracks cannot open further, it need contracts the wall, by wire rope. The surface of the adobe wall is friable, it not keep the painting and the plaster. We can help on this, that on the surface we fix a thin wire mesh with big nails and we plaster thin in a traditional manner (Fig. 10.). The renovated adobe wall building is not only power saving and healthy (for example humid balancing), but it emits very calming mood, because of its traditional formation $[27,33]$. 


\section{Conclusion and outlook}

In this work, we were dealing with some aspects of the the adobe walled house. The example was approached through the vernacular architecture of the authors homeland, Hungary. The climate of Hungary is continental, which hot summer and cold winter are meant. Due to the climatic relationships the large heat capacitance capability walls are the most ecological in this climate. The soil and terrain conditions allow the construction from the earth. The earth and adobe walling have large heat-storage capability. In this way was formed, that one of the characteristic form of the Hungarian vernacular architecture is the building form adobe.

At the beginning of this paper, we were shown, that the significant part of the hungarian building stock consists still adobe wall buildings. Because these buildings are historic or historic like buildings, therefore their conservation and bequeath for the posterity is very important, from the viewpoint of cultural heritage. Unfortunately, in the mind of one part of the inhabitants, the concept of the adobe wall house connected to the concept of the povetry. Due to this fact, the adobe houses are not appreciated too much by the ordinary people. If this is possible, these houses are demolished and instead they, characterless brick wall houses are built. So, the traditional, to landscape fitting villagescape changes.

In this paper, we were shown, that the approximately half-meter thick adobe wall is capable to seasonal heat balancing. The heat storage of the adobe wall is very large. During the hot summers, the inner climate of the adobe wall house is pleasantly cool, air-conditioning system is not necessary. In these walls, the winter cold is stored. During the summer time, the thick walls warms up, and they provide comfortable inner climate in the transitional autumn time and at the end of the spring period. Only in the winter and in the beginning of the spring is necessary to heat. In the unheated adobe building, because of the heat storage property, the water can not freeze, whatever cold is outside. According to our recent knowledge, electrotechnical modell for the description transient heat behaviour of adobe walling was firstly used by us.

In the next part, it was shown by the life-cycle assesment, that it is more suitable to restore the adobe wall building, than is it demolished and built a new one instead of it. The demolition of the old building and the construction of the new building are energy demanding as well. If we take into consideration, that the general usage of air conditioning system caused by global waring up, the maintenance of old adobe building is cheaper compared to the replaced new building. If the unquantifiable cultural heritage is also considered, then the preservation of the adobe wall house in any case is advantageous. Related to our present knowledge, the comparative life cycle assesment of brick wall house and adobe wall house for the Hungarian relations are investigated by us firstly.

In the last section, some questions of the conservation of the adobe wall building is discussed. The additional protection against moisture of the adobe walling is alreday solved. In this field, various chemicals and technologies are available. In this paper, we focused on two areas. One of them was the prevention of the crack propagation, when possibly cracking appeared on the walling. The other thing was the stability solving of inner plaster. Compared to usual solutions, here, new solutions made by new material and new technology were shown. An important character of these introduced 
solutions, that they were proved system, and they were published around after ten years positive experiences.

\section{Remarks and acknowledgements}

Target: The purpose of the article is theoretical and practical background for the conservation of the cultural heritage adobe wall buildings.

Methodology: For the description of an adobe wall building transient, an electrotechnical model is applied. Here, the heat flow is determined with the usage of an electrical network, which is consisted from resistances and capacitances. For the demonstration of ecological advantages, life cycle assesment is used. For the stability preservation and for the comfort improvement, well proved constructional solutions are used, they have stood out the test of the time.

Output: The present work contains three main conclusions. The modeling shows, that the thick adobe walling is suitable for the seasonal heat balance. The result of the life cycle assessment presents, that the preservation and renovation of the old adobe wall buildings is more ecological solution, than their demolition, and instead of they building of new brick wall houses. This conclusion is proved with the consideration of long term building maintainance as well. The suggested solutions of the building renovation are confirmed by many year experiences.

Originality: In the stationare case, the electrotechnical modeling such as heat-resistance is widely known. According to our knowledge, similar transient electro-technical approach for the heat technical modeling for the adobe walling was used firstly by us. The demonstrated wire roped stability fixing is our own idea. This solution is applied first time more than thirty years ago, which is ensured the trials of the time, therefore it is offered to apply courageously for others as well.

Acknowledgements: The authors want to acknowledge the invaluable help of Architect Gilkauris Rojas for the edition of the manuscript. Further more, the first author is indebted for the fruitful discussion with Jaume Roset (Universitat Polytecnica Catalunya, Barcelona). This work carried out in the frame of COST TU1104 project.

\section{References}

[1] Nemcsics, Á. (1999). Environment friendly and ecological architecture. En: KKMF (ed.). Budapest: KKMF,

[2] Nemcsics, Á. (2012). Some aspects to the pollution reduction related with built environment. Óbuda University e-Bulletin [en línea], vol. 3, pp. 1-12. Disponible en: http://uni-obuda.hu/ebulletin/Nemcsics_3.pdf.

[3] Nemcsics, Á. (2007). Earth houses or the earth as a ecological building element in the ecological architecture. Bioépítészet. Szeged: Bába, pp. 96-114.

[4] Gráczer, Z., (2015). Hungarian National Seismological Bulletin. Budapest: MTA. http://www.szeizmologia.hu/data/src/bulletins/HNSB_2015.pdf 
[5] Report of Seismological Observatory,. Kövesligethy, Radó Szeizmológiai Obszervatórium, Budapest: http://www.seismology.hu/index.php/en/.

[6] Istvánfi, Gy. 1997. History of the architecture, prehistoric age and the vernacular architecture. Budapest: Nemzeti Tankönyv Kiadó.

[7] Szűcs, M. (1996). Building of soil and adobe walling. Budapest: ÉTK.

[8] Miller, T. (1999). Lehmbaufibel; Bauhaus-Universitätsverlag Weimar

[9] Minke, G. (2001). Das neue Lehmbau-Handbuch. Staufen bei Freiburg: Ökobuch.

[10] Minke, G. (2009) Handbuch Lehmbau: Baustoffkunde, Techniken, Lehmarchitektur; ÖkoBuch Verlag

[11] Dachverband Lehm e.V. (2008). Lehmbau Regeln: Begriffe - Baustoffe - Bauteile; Tubner Verlag

[12] Larkin, D. Romero, O. (1994). Adobe; Published by Houghton Mifflin

[13] McHenry, P.G. (1989). Adobe and Rammed Earth Buildings: Design and Construction; the University Arizona Press

[14] Romero, O., Larkin D. (1994). Building and Living With Earth; Publ. by Houghton Mifflin

[15] Röhlen, U. Ziegert, C. (2014). Lehmbau-Praxis: Planung und Ausführung; Beuth Praxis Taschenbuch Verl.

[16] Sanchez, L. Sanchez, A. (2008). Adobe Houses for Today: Flexible Plans for Your Adobe Home; Publisher: Sunstone Press

[17] Schroeder, H. (2103). Lehmbau: Mit Lehm ökologisch planen und bauen; Springer Verlag

[18] Schroeder, L., Ogletree, V., (2010). Adobe Homes for All Climates: Simple, Affordable, and Earthquake-Resistant Natural Building Techniques; Chelsea Green Publishing Company

[19] Stedman, M. (2016). Adobe Architecture, A Simple Guide with Plans for Building with Earth; Brand Sunstone Press

[20] Nemcsics, Á. (1996). Wärmebilanz der Lehmwand oder Modelling vom Wärmetransport. Energy and Mass Flow in the Life Cycle of Buildings. Aug. Vienna: s.n., pp. 639-642.

[21] Rusirawan, D. (2012). Energetic modelling of photovoltaic modules in grid connected systems. S.l.: Theses at Szechenyi University, Gödöllő.

[22] Gereben, Z. (1981). Building physics for architekts. Budapest: Műszaki.

[23] Lohmeyer, G. (1992). Praktische Bauphysik. Stuttgart: B.G. Teubner.

[24] Géher, K., (1975) Linear networks. Budapest: Műszaki.

[25] Balabanan, N. (1958) Network Synthesis. New York: Engelwood Cliffs.

[26] Cauer, W. (1960). Theorie der linearen Wechselstromschaltungen. Berlin: Akad. Verl.

[27] Nemcsics, Á, Ürmös, A. (2013). The adobe wall as an ecological building structure, Proc. of ELCAS3, 7-9 July , Nysiros Greece.

[28] Guinée, J.B., (2002) Handbook on Life Cycle Assessment: Operational Guide to the ISO Standards; Kluwer Acad. Publ.

[29] Klöpffer, W., (2014) Background and Future Prospects in Life Cycle Assessment; Springer

[30] Hegedűs, B., Vágó, D., Gröller, Gy., (2013) Dissertation with LCA thematics at the Obuda University; proc. of VIII LCA Conf, Budapest. 
[31] www.gabi-software.com

[32] www.thinkstep-anz.com/software/gabi-lca-software/

[33] Traugott, J., (1998) Pueblo Architecture and Modern Adobes: The Residental Designs of William Lumpkins; Museum of New Mecóxico Press. 